(C) 1983 ISIJ

\title{
鋳型内電磁攪拌によるリムド相当鋼の連続鋳造
}

\author{
竹内 栄一*. 藤井 博務 ${ }^{* 2} \cdot$ 大橋 徹郎 ${ }^{* 3} \cdot$ 円野 仁 ${ }^{* 2}$ \\ 高尾 滋良*2.古垣一成*2. 喜多村治雄*4
}

\section{Continuous Casting of Pseudo-Rimmed Steel with Electromagnetic Stirring in the Mold}

\author{
Ei-ichi Takeuchi, Hiromu Fujil, Tetsuro Ohashr, Hitoshi Tanno, \\ Shigeyoshi TAKao, Issei Furugaki, and Haruo KrTAmura
}

Synopsis :

Realization of the continuous casting of undeoxidized steel is one of the most important tasks in continuous casting technology.

This report describes the development of production of the pseudo-rimmed steel with the electromagnetic stirrer installed in the mold.

(1) To produce a good slab free from CO blowholes in the subsurface layer, it is necessary to make the factors suitable, such as the position of the linear moters, stirring conditions and the shape of mold.

(2) Pseudo-rimmed steel of sol. $\mathrm{Al} \leq 0.004 \%$, which is equivalent to rimmed or capped steel, can be continuously cast by electromagnetic stirring the molten steel in the mold.

(3) The movement of the molten steel also has beneficial effects on the slab quality, such as uniformalization of shell thickness and reduction of inclusions near the subsurface layer.

\section{1. 緒言}

未脱酸鋼を連続鋳造で製造する試みは古くから各国で 行われており，幾つかの実施例が報告されている1) 3). しかしながら操業性, 品質等の点で問題点を抱えいまだ 生産段階に至つていない，このため現在の連鋳鋼種はキ ルド鋼を前提としておりリムド，キャップドならびにセ ミキルド鋼は過剩の $\mathrm{Al}, \mathrm{Si}$ で脱酸され鋳造されている のが現状であり，これに伴う品質上の問題点，合金原単 位の増加は連鋳技術の大きな課題となつている.

これらの問題点に対する従来のアプローチとしては， Riband 鋼4)にみられるよらにキルド領域内で溶質濃度 を制御することによつてリムド鋼に近い成分を得ようと するものが主体5)であり， $\mathrm{CO}$ 気孔発生を伴らリムド鋼 相当材を鋳造したものとは言い難い.

本研究は電磁攪挥装置を内蔵した連鋳スラブ用鋳型を 用い，前報6）で述べた溶鋼流動による気孔制御を行らこ とによりリムド，キャップド鋼と同等の材質を有する鋳
片を得ることを目的としたものである。

\section{2. 鋳型内電磁攪拌装置}

\section{$2 \cdot 1$ 装置の概要}

Fig. 1 にスラブ用鋳型内電磁攪拌装置の概要を示す. 鋳型長辺部の水箱内にリニアをーターを設置しており,

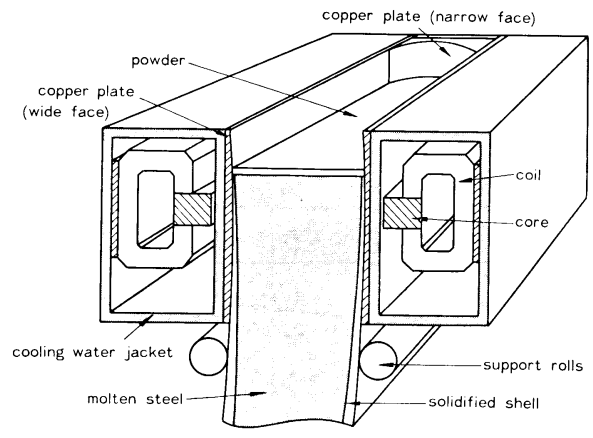

Fig. 1. Schematic view of electromagnetic stirring in the mold (EMS-M).

昭和 57 年 4 月本会講演大会にて発表 昭和 57 年 11 月 25 日受付 (Received Nov. 25，1982)

* 新日本製鉄 (株) 本社 (Nippon Steel Corp.)

*2 新日本製鉄 (株) 広畑製鉄所 (Hirohata Works, Nippon Steel Coorp., 1 Fuji-cho Hirohata-ku Himeji 671-11)

*3 新日本製鉄 (株) 広畑製鉄所 工博 (Hirohata Works, Nippon Steel Corp.)

*4 新日本製鉄 (株)工作事業部 (Engineering Business Operation Bureau, Nippon Steel Corp.) 
鋳型幅方向に㧍のおの逆方向の推力を与息ることにより メニスカス近傍に水平方向の溶鋼旋回流を得ることがで きる，そのため短辺部は淀及を生じない上らに曲率を持 たせた構造になつている.

一般に銅板を介して溶鋼に与兄られる電磁力は後に述 べるように銅板厚が増すにつれ指数関数的に減衰する.

このため, 銅板厚を極力薄く, から冷却板としての十分 な剛性を有する構造について検討し，銅/非磁性ステン レスの複合冷却板が開発された ${ }^{7)}$. 薄肉銅板とステンレ スは爆着により接合されて扔り, 十分な強度, 耐久性を 有するものである.

\section{2 電磁睍拌力と釷型内流動パターン}

電磁摫拌状沉をシミュレートする目的でフューズドメ タル実験を行つたＰ Pb 30 atm/o, Sn 20 atm/o, Bi 50 atm/oから成るフューズドィタルはステンレス製の槽中 で底に配管したスチームパイプにより， $140^{\circ} \mathrm{C}$ に加熱保 持されている.この槽の外面に種々の厚みの銅板を取り 付けることがでさ，その外側に設置したリニアモーター によりフューズドメタルを駆動させるものである、Table 1 亿実験条件を示す．Fig. 2 亿鋳型幅中央部での流速 に及ぼす銅板厚およびメニスカスとりニアモーターのコ アーセンター間距離の影響を示す。なお，流速測定は回 転式流速計にて行つた. リニアモーターのコアー位置で の流速は 銅板厚のみに 依存しているのに対し, メニス

Table 1. Experimental condition of fused metal model.

\begin{tabular}{ccccc}
\hline Fused metal & $\begin{array}{c}\text { Composition } \\
(\text { atm/o) } \\
\text { Temperature }\end{array}$ & $\begin{array}{c}\mathrm{Pb} \\
140^{\circ} \mathrm{C}(\text { Melting point }\end{array}$ & $\begin{array}{c}\mathrm{Sn} \\
\text { Mold }\end{array}$ \\
\hline Mold & $\begin{array}{l}\text { Dimension of SUS } \\
\text { bath } \\
\text { Thickness of Cu } \\
\text { plate } \\
\text { Meniscus } \\
\sim \text { Motor core }\end{array}$ & $240(\mathrm{t}) \times 1650(\mathrm{w}) \times 870(\mathrm{~d})(\mathrm{mm})$ \\
\hline
\end{tabular}

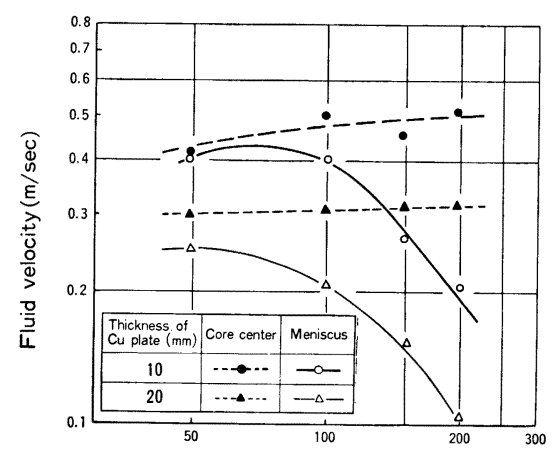

Distance between meniscus and core center $(\mathrm{mm})$

Fig. 2. Effect of distance between meniscus and core on the fluid velocity.

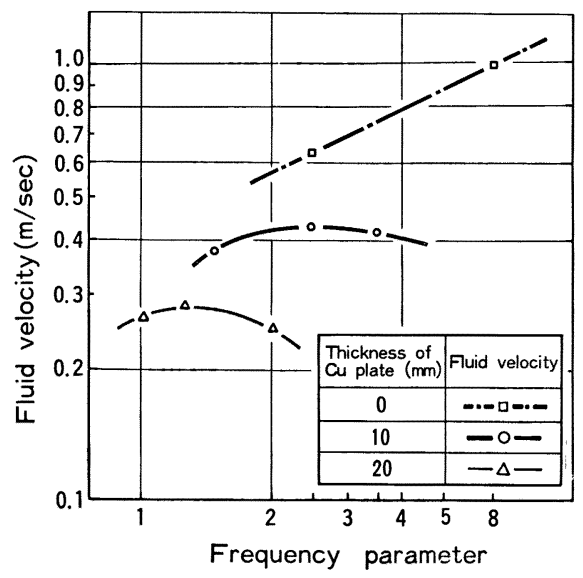

Fig. 3. Relationship between frequency and fluid velocity.

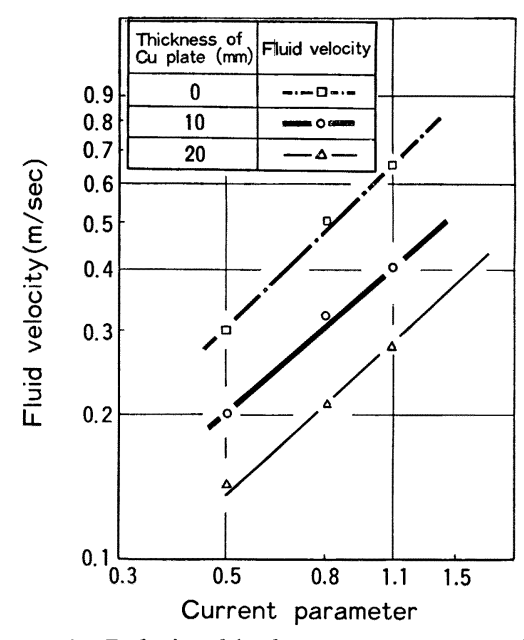

Fig. 4. Relationship between current and fluid velocity.

カスでの流れは銅板厚のみならず, コアーとメニスカス 間距離にも依存して拉り，その距離が $40 \sim 70 \mathrm{~mm}$ の間 で最大となつている. Fig. 3 は鋳型内の攪拌推力およ びメニスカス流速に及ぼす銅板厚と電源周波数の影響に ついて示したものである. な扰推力とはフューズドメタ ルが無い状態でュアー前面に設置した真鍮板にかかる力 を溶鋼の位置エネルギーの指数に置き代えたものである が，そこに銅板が介在する場合最大の推力を与える周波 数が存在し，その值は銅板厚により異なつている. また メニスカスに怙ける流速も推力と同じ周波数で最大值を 示している. Fig. 4 は推力および流速と電流值との関 係を示したものであるが対数軸上で両者は直線関係を示 し，その傾きは銅板厚に関係なく一定である. 


\section{$2 \cdot 3$ 電磁攪拌推力の理論的推定}

溶鋼内での電磁界は Maxwell の方程式によつて与 光られる. 鋳型長辺部でのコアー前面に括活る二次元 Maxwell 方程式は次式となる.

$$
\partial^{2} \boldsymbol{B} / \partial x^{2}+\partial^{2} \boldsymbol{B} / \partial y^{2}=\sigma \mu(\partial \boldsymbol{B} / \partial t)
$$

ここで， $\boldsymbol{B}$ : 磁束密度， $\sigma$ : 電気伝導度， $\mu$ : 透磁率 溶鋼中比発生方方進行磁界の磁束密度は上記 ( 1 )式を 空気銅板，鋳片の各部位に执いて解くことにより得られ るがその解はきわめて複雑となる，定性的な理解を得る ために概峈近似を前提とすると以下の式が成立する ${ }^{879)}$.

$$
B=C_{1} \cdot J \cdot \exp \left[-C_{2} \cdot d \sqrt{\sigma_{\mathrm{e}} \cdot f}\right]
$$

ここで, $C_{1}, C_{2}$ : 定数, $d$ : 銅板厚, $\sigma_{\mathrm{c}}$ : 銅板の電気 伝導度, $f:$ 周波数, $J:$ 䚑汼コイル電流密度

他方，溶鋼中に磁束密度 $B$, 速度 $2 \tau f$ の進行磁界加 発生している場合, 溶鋼単位長さに発生する誘導起電力 E以

$$
E=\sqrt{2} B \cdot \tau \cdot f
$$

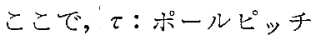

溶鋼の導電率を $\kappa$ とすれば溶鋼中を流れる誘導電流 $I$

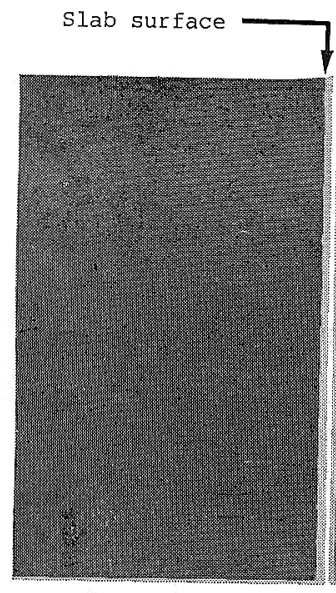

i) With EMS-M

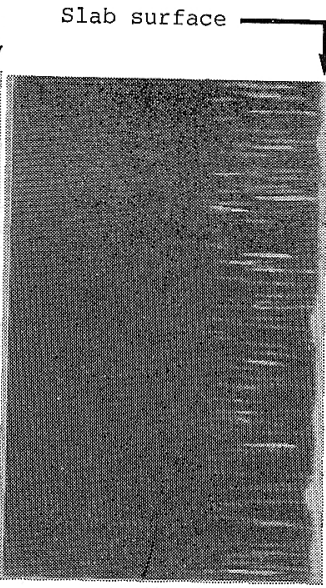

ii) Without EMS-M

$0 \quad 10 \quad 20 \quad 30(\mathrm{~mm})$

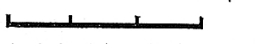

Photo. 1. Suppression of CO blowhole with EMS-M.
惊

$$
I=\kappa \cdot E=\sqrt{2} \kappa B \tau f
$$

従つて，溶鋼に働く力Fは，

$$
F=B^{2} \cdot f \cdot \kappa \cdot \tau
$$

となり，(2)式と(5)式とを組及合わせて次式を得る

$$
F=C_{1}^{2} J^{2} f_{\kappa} \cdot \tau \exp \left[-2 C_{2} d \sqrt{\sigma_{\mathrm{c}} \cdot f}\right]
$$

これが溶鋼に作用する攪拌力を与光る式であり，また この $F$ を位置エネルギーで表示すると，溶鋼流速 $V$ は

$$
\begin{aligned}
V= & C_{3} \sqrt{2 g F}=C_{1} C_{3} J \sqrt{2 g f \kappa \cdot \tau} \\
& \times \exp \left[-C_{2} d V \overline{\left.\sigma_{\mathrm{c}} \cdot f\right]}\right] \ldots \ldots . .
\end{aligned}
$$

で与觉らる。

既に述べたFig. 3，4の結果は(6)，（7)式とも一致 し，攪拌力ならびに溶鋼流速はュイル電流に比例し，周 波数については最大值を有し，かつ銅板虽みについては 指数関数的な影響を受けることが理論的に裹付汀られ t.

\section{3. 䤻型内電磁攪拌による鋳造実験}

\section{1 実験方法}

転炉で溶製した鋼を真学脱ガス装置 $(\mathrm{RH})$ にて脱酸 微調整をはじめとする成分コントロールを行い，鋳型内

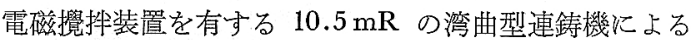
鋳造を行つた，実験条件を Table 2 飞示した。溶鋼組 成はリムド，キャップド鋼に相当する冷延用低炭材であ る。鋳片はとの表面性状を観察するととも火所定の位置 からサンプルを採取し，気孔発生状沉，凝固組織，介在 物分布等について調查した。ささにラジオアイソトープ を用いた鋳型内凝固プロフィールの調査，鋳型内抜熱量 の変化等についてb検討を行つた.

\section{2 鋳片表層部の気孔抑制}

溶鋼流動による気孔制御の原理は前報6)で述べたとお

\begin{tabular}{|c|c|c|c|c|c|c|}
\hline \multirow[t]{2}{*}{ Chemical composition $(\%)$} & $\underline{\mathrm{C}}$ & $\underline{\mathrm{Mn}}$ & $\underline{\mathrm{Si}}$ & $\underline{P}, \underline{S}$ & Sol.AI & $O_{\text {free }}$ \\
\hline & $0.01 \sim 0.08$ & $0.10 \sim 0.25$ & $0.01 \sim 0.02$ & $0.010 \sim 0.020$ & $\leq 0.004$ & $0.0010 \sim 0.0120$ \\
\hline \multirow{5}{*}{ Casting condition } & \multicolumn{2}{|c|}{ Temperature of molten steel } & \multicolumn{4}{|c|}{$1562 \pm 12^{\circ} \mathrm{C}$} \\
\hline & \multicolumn{2}{|c|}{ Casting speed } & \multicolumn{4}{|c|}{$0.06 \sim 1.10 \mathrm{~m} / \mathrm{min}$} \\
\hline & \multicolumn{2}{|c|}{ Mold size } & \multicolumn{4}{|c|}{$1120 \sim 2100(\mathrm{~mm}) \times 250(\mathrm{~mm})$} \\
\hline & \multicolumn{2}{|c|}{ Immersion nozzle } & \multicolumn{4}{|c|}{$105 \phi \mathrm{mm}$} \\
\hline & \multicolumn{2}{|c|}{ Meniscus $\sim$ Motor core } & \multicolumn{3}{|c|}{$50 \pm 10(\mathrm{~mm})$} & \\
\hline
\end{tabular}
りである，本実験で用いた鋳型内電磁攪拌装置はメニス カス近傍で水平方向の旋回流を得ることができるもので あり，所定の凝固厚まで気孔のない層を鋳片全面にわた つて得るものである。

Photo. 1 は $[\mathrm{C}] 0.04 \% ，[\mathrm{O}] 80 \sim 100 \mathrm{ppm}$ の溶鋼学 推定流速 $1.0 \mathrm{~m} / \mathrm{s}$ の攪汼条件で鋳造した場合の表面気孔

Table 2. Experimental condition of pseudo-rimmed steel. 


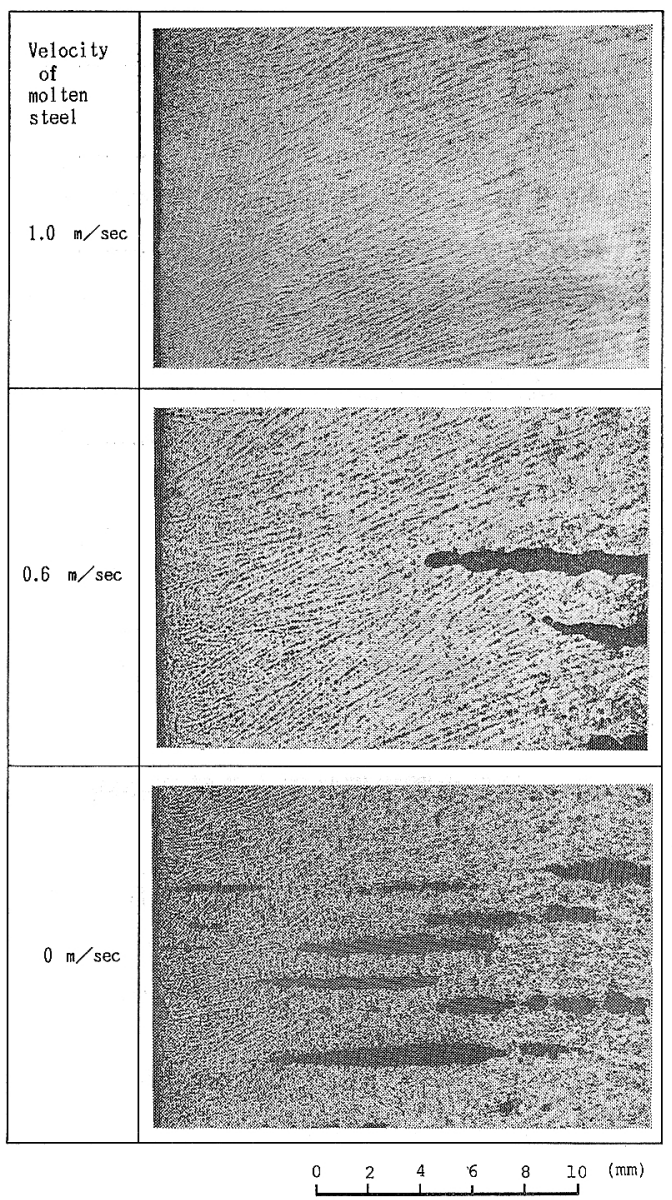

Photo. 2. Dendrite structure of EMS-M slab surface.

の抑制状況をX線透過写真にて示したものである. 観察 場所は鋳片断面の愊中央部表面近傍で放る．無挸汼の場 合気孔以 鋳片表層直下から数多く発生しているの以対 し，電磁覔汼材では表面での気孔発生は抑制されている とともに鋳片内部に残存している気孔数も激減してい ๖.

Photo. 2 亿各種㩭汼下での鋳片表層凝固組織を示す. 無挸找材では，デンドライトは鋳片表面に垂直に発達し

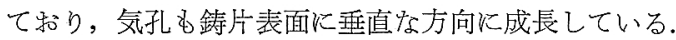
他方，挩拌に上る溶鋼流動が付与された場合，デンドラ イトは流動の方向に向かつて成長して括り溶銅流速が大 になると気孔発生は完全に㧕制される。さらに興味深い ことは流速が弱くなり気孔が発生している部位に拈いて 気孔は表面烧して垂直，小いか党ると凝固の進行方向 に成長して抢り，必ずしもデンドライトアームに拘束を 受けていないことである。これは溶鋼流動による気孔の

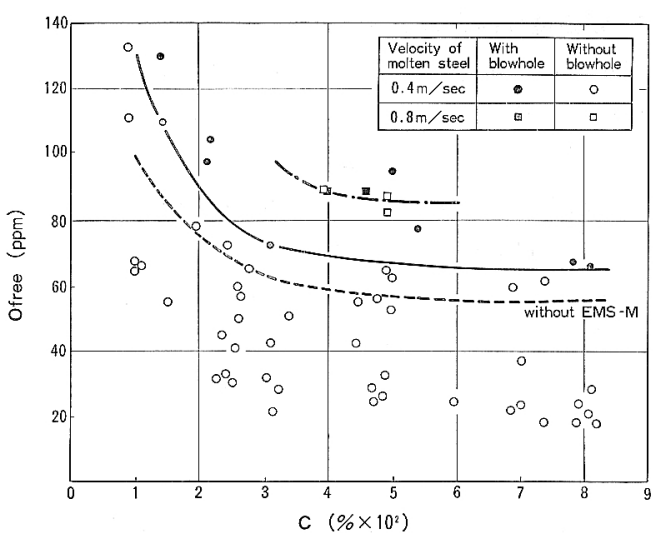

Fig. 5. Ghange of critical composition of $\mathrm{CO}$ blowhole formation with EMS-M.

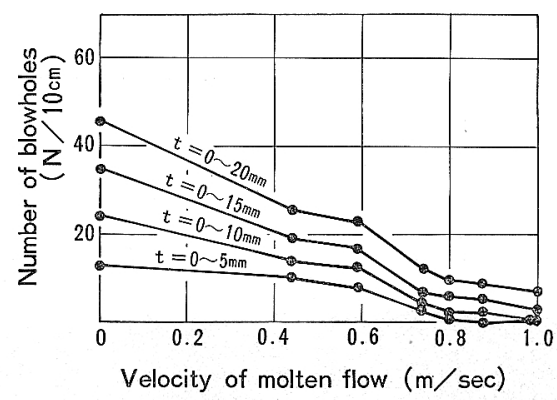

Fig. 6. Relationship between the number of $\mathrm{CO}$ blowhole in wide face of the slab and the velocity of molten flow.

抑制機構を考克る上で重要な現象で步る.

同様な調査を種々な $[\mathrm{C}],[\mathrm{O}]$ 系について行い，気 孔発生状況々電磁攪汼の関係を, Fig. 5 に示した. 気 孔発生限界以溶鋼流速が增大寸るにつ机て高酸素側认移 行し, $0.8 \mathrm{~m} / \mathrm{s}$ 程度の 流速で約 $40 \mathrm{ppm}$ 高くなつてい る. な洛，この気孔発生限界は鋳片表面を $0.5 \mathrm{~mm}$ スカ 一フした後の目視観察結果に基づくもので少る.

末た，先炕示した $[\mathrm{G}] 0.04 \% ，[\mathrm{O}] 80 \sim 100 \mathrm{ppm} の$ 溶鋼化鋳型内 電磁攪拌を作用さ也溶鋼流速を $0 \sim 1.0$

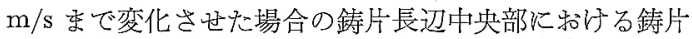
厚み方向の気孔分栃をFig. 6 飞示した。 こ机は鋳片断 面を磁粉深傷法に上り調査したるのでする。鋳片表面か

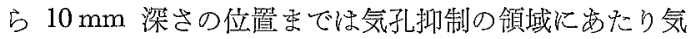
孔個数梳速が增す见つれて娍少し， $0.8 \mathrm{~m} / \mathrm{s}$ 以上で性

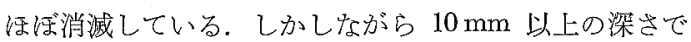
の気孔については変化が少なく本装置が政型の上半分の

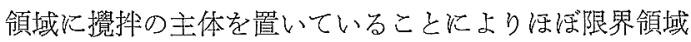
々考光られる。また溶鋼流速は気孔径にも影響を招よぼ 
し，溶鋼流速が大になるにつれ気孔径は小さくなり，0.8 $\mathrm{m} / \mathrm{s}$ 以上になつて消滅している。 この現象についても既 に前報で述べた理論推定傾向と一致している.

\section{3 鍀型内凝固現象と鋳造組織}

既に Photo. 2 に示したように溶鋼流動によつてデン ドライトは傾斜する，各流速に打けるデンドライトアー ム傾斜角度を Fig. 7 亿示した. この傾斜角は鋳片表面 から 5 10 mm の間の平均值を用いた，傾斜角は流速の

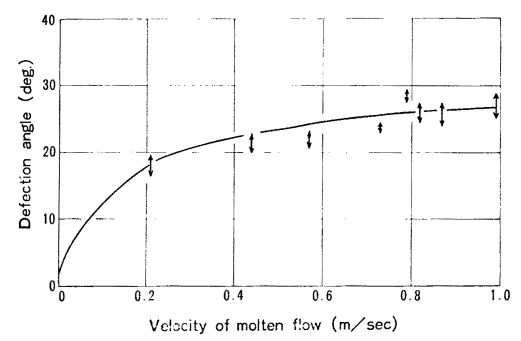

Fig. 7. Relationship between the deflection angle of dendrite and the flow velocity.

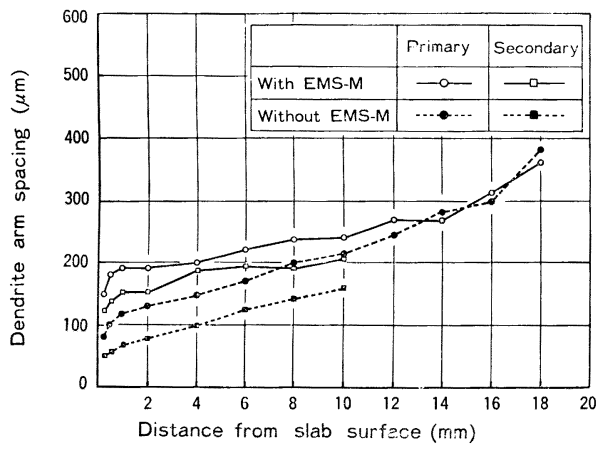

Fig. 8. Effect of EMS-M on the dendrite arm spacing.

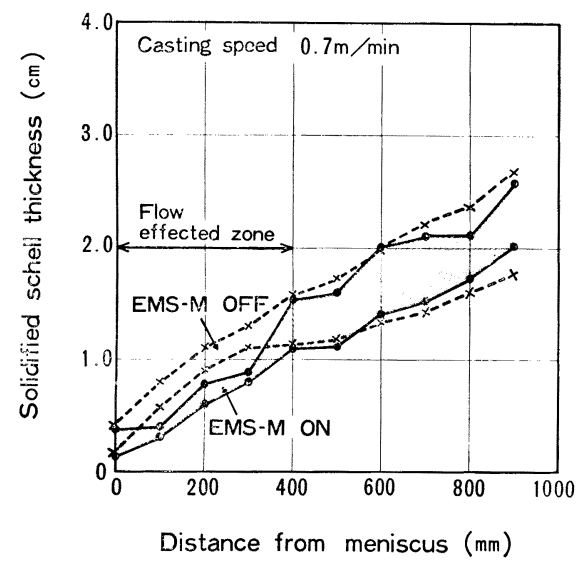

Fig. 9. Solidified shell profile of EMS-M slab.

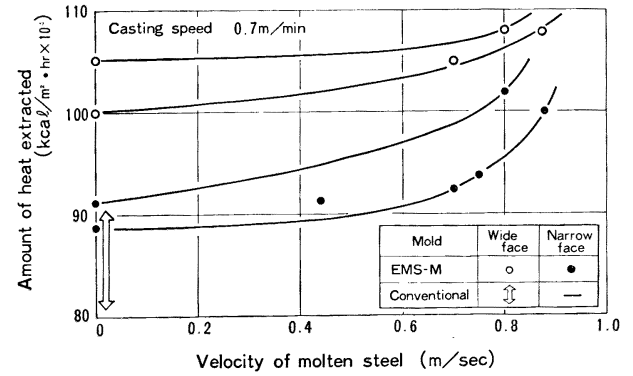

Fig. 10. Relationship between the velocity of molten flow and the heat extracted in the mold.

増加につれて增大するが $0.8 \mathrm{~m} / \mathrm{s}$ 以上ではその変化は小 さくなり，約 $30^{\circ}$ で飽和状態になる。この傾向は高橋 ら ${ }^{10)}$ の結果と一致している.さらに Fig. 8 亿溶鋼流速 0 と $1.0 \mathrm{~m} / \mathrm{s}$ の時の鋳片表層部のデンドライトアーム間 隔を示す．流動によりアーム間隔は一次，二次共に拡大 する方向に向かい，流動域の終わる表層から 10〜12 mm 以上では差が認められなくなる。この現象は流動による 凝固速度の低下を示唆するるのである11) と考兄られるの で，次にラジオアイソトープ添加に上る鋳型内凝固殼の 発達状況を観察した．結果は Fig. 9 に示すように鋳型 内電磁擋拌の影響域では凝固厚は無穓拌の場合に比べ薄 くなつて拈り，かつそのばらつきも小さく均一な発達を 示している.

電磁摫拌鋳型は従来の鋳型に比べ銅板厚が薄いことに 加え溶鋼流動の影響があることから鋳型内伝熱挙動は従 来のものとは異なつている. Fig. 10 亿冷却水温差から 計算した鋳型抜熱量の流動依存性を示した．銅板の薄肉 化により流動が弱くても拔熱量は従来鋳型に比べ 10 $20 \%$ 増加しているが，これ攪挥流動が 作用するとし だいに拔熱量が上昇し， $0.8 \mathrm{~m} / \mathrm{s}$ の流速ではさらに 10 \%の増加となつている. 流速の增加による拔熱量向上 の原因としては電磁䚇拌による 液側伝熱境膜の 変化 ${ }^{12)}$ や，エャーギャップの生成時期の変化，パウダー流入状 況の相異などが考えられるが推定の域を出ない。

\section{4 鋳片表層溶質分布とオシレーションマーク}

凝固前面の溶鋼流動に上る溶質の負偏析に関しても従

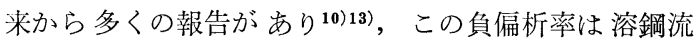
速，凝固速度に大きく依存していることが 知られてい る.

Fig. 11 飞溶鋼流速が $1.0 \mathrm{~m} / \mathrm{s}$ の場合の 鋳片表層の [C] 分布を示した. 鋳片表面直下 $1 \sim 2 \mathrm{~mm}$ では凝固速 度が 大きいため顕著な負偏析は生じていないが $5 \sim 15$ $\mathrm{mm}$ 部位で大きな負偏析が得られている，これを取鍋成 分に対する負偏析率で表示し，その最大值と溶鋼流速と 


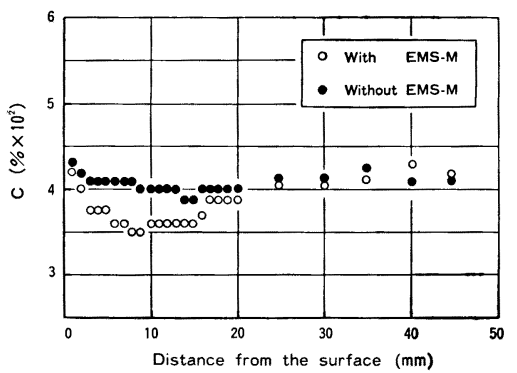

Fig. 11. Negative segregation in the surface layer of EMS-M slab.

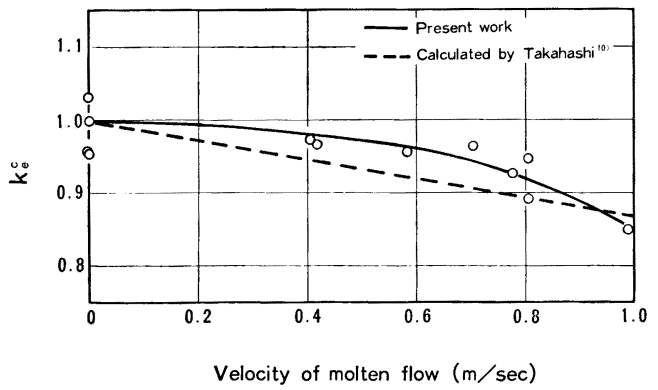

Fig. 12. Effect of the velocity of molten flow on the effective distribution coefficient of $\mathrm{C}$.

の関係を Fig. 12 に示した. 流速の増大に伴い負偏析率 は大きくなる様子が知れる．なお参考のために高橋ら ${ }^{10)}$ による計算結果も併示したが両者は比較的良く一致して いる. このことは今回推定した溶鋼流速が妥当な值であ ることを示しているものとも理解される.

次に攪挥流によるオシレーションマーク深さの変化を Fig. 13 に示した. 流速の増大に伴いオシレーションマ ークは浅く，またばらつきが少なくなつていることがわ

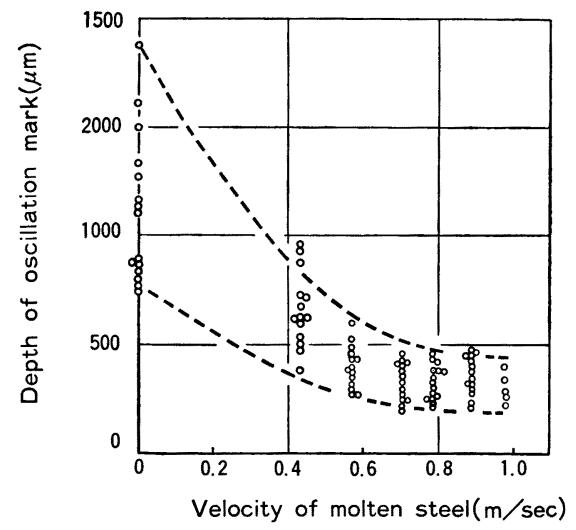

Fig. 13. Effect of EMS-M on the depth of oscillation mark.
かる.この状況は Photo. 1 からも明瞭に知れる. この 現象は凝固初期にシェルが鋳型に押し付けられるような 力が働いたとみなすより，むしろ摫拌流動によりメニス カス近傍の温度が均一化するとともに上昇し, パウダー の溶融層が厚くなるとともに見かけ粘性が低下すること によるものと推定される ${ }^{14)}$. ちなみに同一鋳造速度, 同 一パウダー下において，電磁靦挥を付与することにより パウダー消費量が約 $20 \%$ 増加しており, 上記推定を裏 付けているものと考觉られ.

以上述べた覺拌による凝固殼の均一化, 負偏析帯の生 成, オシレーションマークの平滑化はいずれも表面疵防 止の観点から好ましいものである.

\section{5 非金属介在物の形態と分布}

鋳型内電磁摫拌と非金属介在物の関係を論じる場合, 第 1 にリムド相当材が製造できることにより，溶鋼中の sol. Al が微量になることに伴ら介在物組成, 形態変化 と第 2 に攪找流動による介在物分布変化に分けられる.

まず前者については, 従来の冷延材用連鋳鋼種である $\mathrm{Al}$ キルド鋼 (sol. $\mathrm{Al} \simeq 0.050 \%)$, 弱 $\mathrm{Al}$ 脱酸鋼 $)^{2}$ （sol. $\mathrm{Al} \simeq 0.010 \sim 0.020 \%$ ）の介在物組成は corundum 域を 出ていないのに対し本研究対象のリムド相当鋼のそれは 低 $[\mathrm{Al}]$ ，高 [O] の故に $\mathrm{MnO}-\mathrm{SiO}_{2}$ 系をベースとし た伸延性介在物の spessartite 系の領域に入つている.

この関係をさらに介在物中の $\mathrm{Al}_{2} \mathrm{O}_{3}$ 濃度と sol. $\mathrm{Al}$ との関係でみると Fig. 14 のようになり, sol. $\mathrm{Al} \leq$ $0.003 \%$ で corundum から spessartite 系へと変化し ている.このような組成変化に伴い. 当然のことながら 介在物形態も変化し, photo. 3 に示すように $\mathrm{Al}$ キル ド及び弱 $\mathrm{Al}$ 脱酸鋼に見られる, $\mathrm{Al}_{2} \mathrm{O}_{3}$ クラスターがリ ムド相当鋼では全く見られず微細球状介在物へと変化し ており，その径も $10 \mu$ 程度ときわめて小さくなつてい る. これらの介在物の生成機構を推定するため溶鋼バル ク中の脱酸反応扎よび前報に示した凝固界面の相互反応

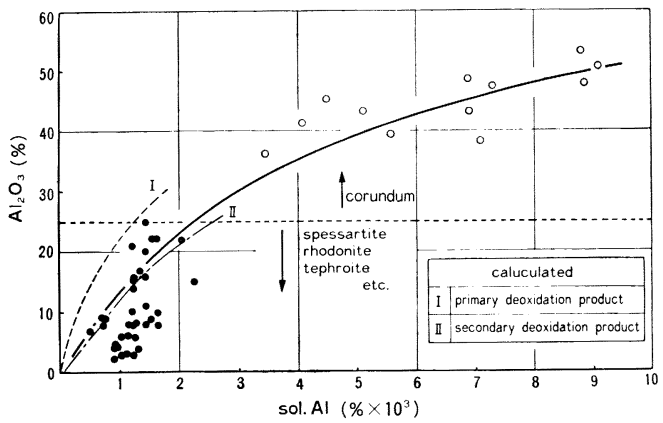

Fig. 14. Relationship between sol. $\mathrm{Al}$ and the composition of non-metalic inclusions. 


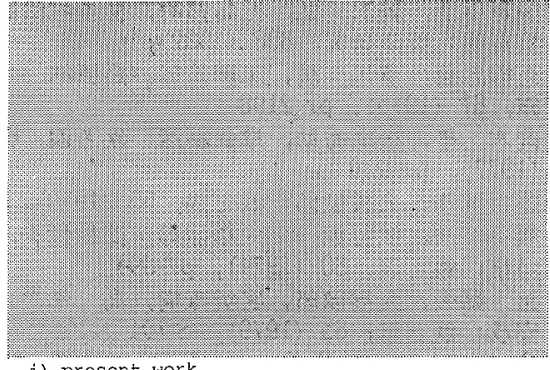

i) present work

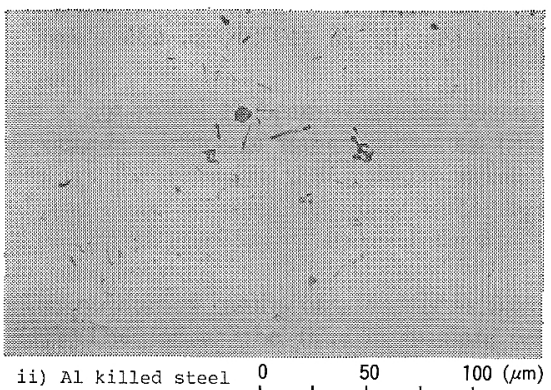

Photo. 3. Typical shape of inclusions in EMS-M slab.

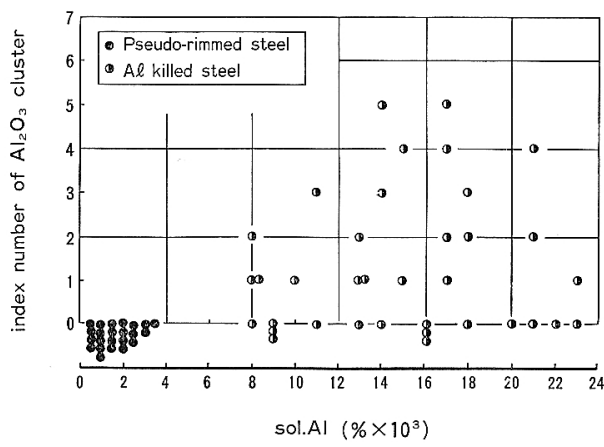

Fig. 15. Relationship between sol. $\mathrm{Al}$ and the number of $\mathrm{Al}_{2} \mathrm{O}_{3}$ cluster in slab.

モデル6) に從い一次脱酸生成物, 二次脱酸生成物の組成 について計算を行つた結果もFig. 14 に示したが，リム ド相当材の主たる介在物が二次脱酸生成物である可能性 を示唆している。

また，リムド相当材に和いては微小介在物が圧延によ りさらに微細に揱断され事実上無害化される。

以上示したよらに，リムド相当材の介在物の形熊, 变 形挙動は成品材質上好ましいもので离り，Fig. 15 に示 す鋳片内 $\mathrm{Al}_{2} \mathrm{O}_{3}$ クラスタ一評点の飛躍的な向上をはじ めとし, 成品での加工性, 表面処理特性等の向上が確認 されている。

次に筧拌による介在物分栃変化についてで市るが，こ

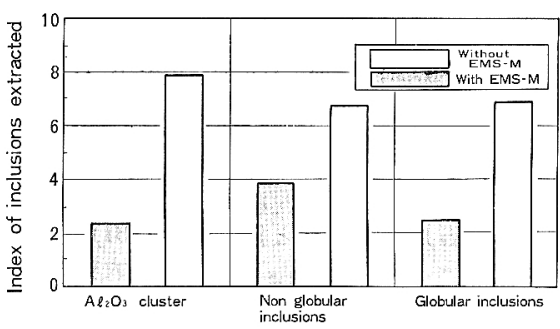

Fig. 16. Effect of EMS-M on the amount of large inclusions in the surface layer of the slab.

れについては，本来の低崖 $\mathrm{A} 1$ キルド鋼を対象とし，主 として大型介在物の分布に焦点をあててスライム法によ る調査を行つた．鋳型内電磁摫抖の溶鍋流速は $0.8 \mathrm{~m} / \mathrm{s}$ である．鋳片幅中央部での表層から $20 \mathrm{~mm}$ 末での介在 物抽出量比較をFig. 16 飞示した. いずれの形態の介在 物量む，攪拌によりほぼ半減していることが知れる。た たし鋳片内部の介在物量については顕著な差が認められ ていない.

ブルームに和ける鋳型内電磁㩭汼沉よる鋳片姜層部の 大型介在物量の改善については既に R. ALBERNY'15) ら の報告があるが，スラブに和いても注ぼ同様の效果が確 認された。

\section{4. 結言}

リムドキャップド相当材の連鋳化を目的としてスラ ブ用鋳型内電磁攪抖装置を開発し, $10.5 \mathrm{mR}$ 湾曲型漙鋳 㙨での実用化実験を行い以下の結果を得た。

1) リニアモーターの設置位置, 㩭抖条件, 鋳型形状 等の基本条件を定めるべくモデル実験を行い，鋳型内電 磁攪拌装置設計の基本仕様を得た。

2) 鋳型内電磁摫拌飞よつて生ずるメ二スカス近傍の 溶鋼流動により鋳片表層部の $\mathrm{CO}$ 気孔発生が抑制され， sol. A1 0.004\% 以下のリムド，キャップド相当材の連 鋳化を達成した。この組成に敀いてはとくた介在物が小 型の $\mathrm{MnO}-\mathrm{SiO}_{2}$ 系になることも出いまつて，成品での 表面性状，加工性等の改善が見られる.

3）鋳型内流動により，凝固殻発達が均一となり，鋳 片表層に負偏析帯が生じるとともにオシレーションマー クが平滑になる。これらは鋳片表面疪防止に効果的炕寈 与する为のと考光られる.

4) 完全脱酸鋼への適用に際しても種女の効果が認め られ，とくに鋳片表層の大型介在物の減少が著しい。

$$
\text { 文献 }
$$

1) G. M. Itskovigh and V. B. Gankin: Stal in Eng (1961), p. 407 
2 ) $M$. Tenenbaum, $C . F$. Schrader, and $L$. Mair: JISI, 191 (1959), p. 20

3 ) I. Earnsham, $J . M$. Young, and $B . G$. Boldvin: Elec. Furn. Conf Proc, 24 (1966), p. 41

4) 米国特許 USP 3, 412, 781 (Patented. Nov. 26, 1968)

5 ) 河野拓夫, 長沢元夫, 椿原 治, 細野和典, 江坂 一涁，石飛精助：鉄と鋼，67(1981)，p. 1241

6 ) 竹内栄一, 藤井博務, 宮坟直樹, 大橋徹郎, 平闬 照祥，山広実留：鉄と鋼，69(1983) 14

7 ) 円野 仁, 木村一茂, 藤井博務, 大久保正道, 喜 多村治雄，菊地俊男：鉄と鋼，68 (1982), S 267

8 ) 野中作太郎, 吉田欣二郎: 電気学会誌, $90(1970)$, p. 880
9) 小野田進, 鵜沢 弘, 児島邦明, 喜多村治雄, 山 根良明：製鉄研究，308 (1982)，p. 43

10）高橋忠義, 市川 洌, 工藤昌行, 島原皓一：鉄と 鋼, 61 (1975), p. 2198

11) 岡本 平, 松尾秀助, 荘武勝彦：鉄と鋼，63 (1977)，p. 936

12）藤井博務，大橋徹郎：鉄と鋼，65 (1979)，S 233

13) 熊井 浩, 浅野鋼一, 大橋徽郎, 野村悦夫, 藤井 博務：鉄と鋼，60 (1974), p. 894

14）塗 嘉夫，大橋徹郎，宮坂直樹，島 孝次，打田 安成: 鉄と鋼, 65 (1979), S 701

15) $R$. Alberny, $J . R$. Birat, $J$. Chone, $L$. Angel, $F$. Grethen, $R$. Goetyingen, and $N$. Kaell: Rev. Métall, 76 (1979), p. 235 